\title{
THE PROBLEMS IN PROFESSIONAL COMPETENCE OF TEACHERS IN TEACHING ENGLISH SUBJET AT VOCATIONAL HIGH SCHOOLS
}

\author{
Syamsinar \\ State University of Makassar \\ Hinarishine@gmail.com
}

\begin{abstract}
This research was intended to investigate the problems in professional competence faced by the English teachers of vocational high schools in Gowa, South Sulawesi. This research applied descriptive qualitative method. The data were collected by using three instruments namely questionnaire, interview and observation checklist. The participants were two Experience English teachers, two advanced beginner English teachers, and eight students. The professional competence indicators adapted from the Regulation of the Minister of National Education of the Republic of Indonesia No. 16/2007. The research found that there were eleven problems faced by the teacher in relation to their professional competence. In English teachers' competence especially in linguistic aspect, the major problem faced by the teachers is dealing with lacking of the vocabulary for special terms. In addition, the research also indicated that there were two other serious problems faced by the teachers. First, they faced problem in developing the teacher professionalism continuously. Second, they do not use information and communication for communicating maximally.
\end{abstract}

KEY WORDS: professional competence, expert teachers, advanced beginner teachers.

\section{A. INTRODUCTION}

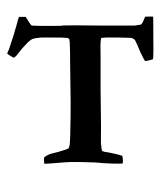

he teachers are professional educators with the primary task to educate, teach, guide, direct, train, assess, and evaluate students in early childhood education, formal education, basic education, and secondary education.

The professional teachers must have academic qualification and competences. The competences that teacher must have namely pedagogical competence, personal competence, social competence and professional competence, the Regulation of the Minister of National Education of the Republic of Indonesia No. 16/2007. Those competences are integrated in teacher performance. As an ideal teacher, she or he must have good qualification, professional and master the four teacher's competence. 
However, Gultom in Antar News (2013) reported that the result of competence examination indicated that the teachers' quality in Indonesia was still low. The average score of the teacher competence test on July 1 $1^{\text {st }}, 2012$ was 47.84 while the passing grade was 65. In addition, Suharini (2009) found that the Geography teachers' professional and pedagogical competence of the school which had A accreditation had good criteria. Whereas, the school which had B accreditation was still in low criteria.

Then the researchers would like to figure out the English teachers' competence of vocational high school. Therefore, they conducted a research for preliminary data about the problems of the English teachers dealing with the teacher competences at vocational high schools in Gowa regency at SMKN 1 SombaOpu and SMKN 2 SombaOpu. The result indicated that the teachers faced problems in pedagogical competence, personal competence, social competence and professional competence. In pedagogical competence, they faced problems mostly in facilitating the development of the students' potentials. The students' potentials in this case are preparing various learning activities and communicating and understanding the effective and polite communication strategies. In social competence, they faced problems in conducting various programs to develop and improve the education quality and communicating with the teachers' community. In personal competence, the teacher faced problems related to the teacher role as a model for the students and society. In professional competence, generally the teachers faced problems in developing material, communicating the material and discourse aspects. Based on the result of preliminary data, the major problems faced by the English teachers at SMKN 1 SombaOpu and SMKN 2 SombaOpuwere professional competence. However, Professional competence is one of the important competences which must be improved and mastered by the English teacher of vocational high school especially toward mastering the subject matter of language aspects. Being successful in teaching process depends on the teachers' ability in developing the material creatively. The role of the teacher's professional competence is considered the most related to the teacher's performance.

Therefore, based on the data, studying the importance of professional competence for English teacher is essential in this research. The researchers focused on seeking the teachers' problems dealing with professional competence in teaching English. 
Syamsinar, The Problems In Professional Competence of Teachers In Teaching English Subjet ...

\section{B. LITERATURE REVIEW}

\section{Teaching Competency}

Professional teachers must have competence. Mulyasa (2002) stated that competence is knowledge, skills, and abilities or capabilities that a person achieves, which become part of his or her being to the extent he or she can satisfactorily perform particular cognitive, affective, and psychomotor behaviours. While Slavík (2008) defined the teacher competence as a set of knowledge, skills and teachers personal qualities. The teaching competency is associated with the complex combination of knowledge, skills, and abilities to have professional performance in the classroom as an educator.

\section{Professional Competence}

Professional competence is the ability in mastering the material to fulfil the standard base competency which has been set by the Minister of Education. The teachers must have a number of standard competences to be professional teacher either based on the Regulation of the Minister of National Education of the Republic of Indonesia No. 16/2007, Slavík (2008) or Bantang (2008). The following is the sub-competences of professional competence based on The Regulation of National Education Minister of Republic of Indonesia.

a. Mastering the material, the structure and the concept of the subject taught

b. Mastering standard competency and basic competencies of the subject taught

c. Developing the learning material creatively

d. Developing their own professionalism

e. Using the information technology

Slavík (2008) categorized the teacher's professional competence into five items, they are as follows;

a. Mastery a systematic body of knowledge.

b. Ability to apply practical experience in the specialization according to the subject of the study.

c. Ability to transform the knowledge based on the subject of study.

d. Ability to integrate the inter-disciplinary knowledge and create subject-links.

e. Ability to use the information and communication technology effectively

The other opinion came from Bantang (2008) who stated that there are some abilities that have to be owned by the teacher related to the professional competence. The abilities are: 
a. Mastering the subject taught

b. Planning the lesson

c. Managing the class

d. Being able to use instructional media

e. Understanding the students' characteristics

f. Being able to select the appropriate materials

g. Being able to conduct an action research

The categories of the three sources about professional competences are related one another. They actually refer to similar requirements for teaching profession. They cover the teachers' competence, such as mastering the subject taught, able to select suitable materials and to use ICT. Nevertheless, if we compare the sub-competence of these three sources, the categorization by The Regulation of National Education Minister of Republic of Indonesia No. 16/2007 is more developed than Slavík's work (2008) and Bantang's work (2008). The Regulation of Minister of Education and Culture 2007 adds and insists the standard competence and the basic competence as one element in teacher professional competence which is not found in other category. Therefore, the researchers used The Regulation of the National Education Minister of the Republic of Indonesia No. 16/2007 as the main indicator in this research which covers the professional competence both suggested by Slavík (2008) and Bantang (2008).

In the previous studies, Suwito (2012) conducted a study on the problems of developing the professional competence of Religion education teachers at MTS PGRI Selur. He raised sixth problems namely the weak capacity of teachers in designing, processing and evaluating the learning; the supporting books; the source of development funding; learning device; lack of guidelines for learning assessment techniques; and lack of improvement and enrichment learning programs. Then, in this this research, the researchers investigated the problems of English teachers at vocational high school dealing with professional competence.

\section{The Professional Competence of Vocational English Teacher}

Generally, the professional competence of senior high school or vocational high school consists of five sub-competences. Nevertheless, the first point of the sub-competence that is mastering the material, the structure and the concept of the subject taught differs for each teacher. The Regulation of the National Education 
Syamsinar, The Problems In Professional Competence of Teachers In Teacbing English Subjet ...

Minister of the Republic of Indonesia No. 16/2007 specified the professional subcompetence for English teacher in particular they are as follows;

a. The teacher must have knowledge about language aspects in English (linguistic, discourse, sociolinguistic and strategies).

b. Mastering the English both written and oral forms, receptive and productive skills in communicative aspects (linguistic, discourse, sociolinguistic and strategy).

Mizne (1999) defined the linguistic competence is the ability of the teacher to use correct grammar, pronunciation, and vocabulary in a language. Discourse competence is concerned with the cohesion and coherence of utterances/sentences. Sociolinguistic competence is the ability of the teacher to produce utterances appropriate to the social situation in which they are spoken. And Strategic competence is how well the person uses both verbal forms and non-verbal communication to compensate for lacking of knowledge in the other three competences.

\section{The English teachers at vocational high school}

It is suggested that the English teachers of vocational high school are required to have positive attitude toward English for specific purpose, knowledge of fundamental principle of the subject area and awareness of what they have already known(Hutchinson \& Waters in Kaimuddin, 1999).

Arnold (1998) in Wello \& Nur (1999) suggested that to achieve effective objectives in teaching ESP, the English teacher and specialist subject in order to give advice and guidance of each other. They also mentioned three ways to improve the ESP teachers' knowledge of the content. First, the teachers can read books and articles on the area written for accountants. Second, develop the numbers of technical terms and define into simpler English. Third, they can also consult with other specialists teachers in the school. So, in improving the ESP knowledge, the English teachers of vocational high school must have effort to find out more references and technical terms.

The teaching and learning process of vocational high schools also has to consider the management of teaching. The management of teaching in vocational high schools should be related to curriculum. Mulyasa (2006) mentioned the management of teaching and learning process in KTSP at vocational high schools include of classroom management, material management, activity and time management, students management, and resource of study. 


\section{Teaching English subject at vocational high school}

Different types of students have different language needs and what they are taught should be restricted to what they need. The teachers of vocational high schools have to teach English that is closely related to the students major of study. They also have to consider the specific needs of the learners that give information related to the special terms. Nevertheless, Kaimuddin (1999) stated that many English teachers at Engineering schools have been teaching for ten or twenty years but they never get opportunity to improve their skill, the teacher realized that there are many special terms should be given but they did not have access for this.

\section{METHOD OF THE RESEARCH}

The aim of this research was to describe the teachers' problems in teaching English in various departments at vocational high schools. This research was conducted by using descriptive qualitative method (Gay, et al (2006). The sampling technique used was purposive sampling technique. The researchers focused on state vocational high schools in Somba Opu district. There were two vocational high schools in this district. They were SMK Negeri 1 Somba Opu and SMK Negeri 2 Somba Opu. The researchers took the expert teachers and advanced beginner teachers of each schools (Dreyfus, 1986). So, the total number of teachers was four. Questionnaires were used for preliminary data to identify whether or not the teacher faced problems related to the teachers' competence. Interview and observation were the instruments used to collect the data about the teachers' problems in professional competence. The researchers used semi-structured interview. They used observation checklist to fit the data that the participants described during the interview. To check the strength of the data, they used data triangulation. This triangulation involved several students at SMK Negeri 1 SombaOpu and SMK Negeri 2 Somba Opu. They employed the data analysis steps based on Miles and Huberman's model in Emzir (2012:129 136). The data were analyzed through data reduction, data display and conclusion.

\section{D.FINDINGS}

The findings of the research are summarized in terms of the problems of the English teachers in professional competence in teaching English at vocational high schools in Gowa. The following is the data obtained from interview and observation from the participants. 
Syamsinar, The Problems In Professional Competence of Teachers In Teaching English Subjet ...

\section{Lacking of vocabularies of special terms for various departments}

There were three of the four English teachers who faced problems in mastering the vocabulary dealing with special terms of various departments.

a) Interview with teacher 1

"The problem is because the school has nine departments, automatically there are a lot of vocabularies which should be suited with the department we taught. The most difficult is Equipment either noun or verb."

b) Interview with teacher 2

"Usually there is vocabulary which is asked by the students and we do not know how to answer because it is too specific."

c) Interview with teacher 3

"There are many vocabularies that I do not know includes noun and verb".

The schools consist of eight and nine departments. The tools or terms which related to their study are different. While teacher 1 , teacher 2 and teacher 3 were not familiar with all the terms or vocabulary used for several departments. The difficult words which the teachers found were nouns and verbs in Equipment and Design Department. During the observation, they never gave the technical terms related to the students' department in constructing the sentences. The students of teacher 1 , teacher 2 and teacher 3 revealed that they had not been given the terms related to their department.

\section{Lacking of pronunciation}

According to the interview data, only one teacher found problem in pronunciation. This case was faced by teacher 3 as presented below.

Interview with teacher 3

"The problem is only a little, for example; the were words which difficult for me to distinguish such as the distinguish of Three: tiga with tree: pohon. If theoretically I can but maybe I am lacking of pronunciation."

There were certain words that she taught were difficult to differentiate in terms of pronunciation especially the words which have similar sounds.

\section{Difficult to communicate the lesson by using English}

Teacher 1 had a problem in applying the strategic competence in communicating the material to make the students understand. The following statement presents her problem. 
Volume I, Number 01, June 2015

Interview with teacher 1

"The problem is when communicating the material; the problem is sometimes if I communicate the material in English, the students do not understand."

In addition teacher 3 also faces problem in communicating the lessons in the class. It can be seen by her statement below.

Interview with teacher 3

"The problem is if we used English sometimes the students do not understand, so we explain in Indonesian language. Sometimes I have also problem, if I communicate in English is not very fluently."

Teacher 3 stated she is not very fluent in communicating the lesson by using English. Due to these problems, the teacher used Indonesian to transfer the knowledge. This is in line with the observation data, during the observation she taught by using Indonesian language in teaching.

\section{Difficult to achieve the basic competence and learning objective}

Based on the interview data, there was one of the teachers found difficulty to reach the target of learning objectives, as she stated in the following interview.

Interview with teacher 1

"If basic competence is a reference for indicators which will be acbieved in learning process, yes actually there is a little problem. This is because of the time allocation in explaining the material is too short. Moreover, we have to reach many learning objectives targets which have been set in the syllabus."

The new regulation of curriculum 2013 which consists of four basic competences and many targets of learning objectives must be achieved in one semester, while teacher 1 had not comprehended the implementation of this curriculum.

\section{Lacking of teaching planning}

The teachers must be well planned before teaching. Based on research findings, there was one of four teachers who did not have a lesson plan during the observation. The following is her statement.

Interview with teacher 1

"T have made lesson plan but it was the previous lesson plan in long time ago."

Teacher 1 owned a lesson plan in the previous semester but this semester she borrows the expert teacher's lesson plan if she faces difficulty. Then, she taught the 
Syamsinar, The Problems In Professional Competence of Teachers In Teaching English Subjet ...

material based on the module instruction without the lesson plan.

\section{Difficult to select the appropriate material}

The teacher must be able to select the appropriate material in teaching at vocational high schools. In interview data, two of four participants faced difficulties in selecting the appropriate materials. They were teacher 1 and teacher 2.

Interview with teacher 1

"This school consists of nine departments, to choose the material is a rather difficult. The obstacle is in applying the material for students, the materials which are presented for students are not wholly specific to their department These material are not appropriate."

Interview with teacher 2

"The problems are, there are several materials which are not familiar with several departments. The second problem is I want to develop the material but I do not have many references."

Teacher 1 stated the material which she taught sometimes did not appropriate with the students. Whereas teacher 2 also realized that the material is not appropriate to be taught for student but she did not change it because of lacking of references.

\section{Difficult to adapt the material to be relevant to students' department.}

There were two teachers faced difficulties to adapt and develop the learning material to be relevant for the students in various departments. They were teacher 1 , and teacher 3 . The problem of teacher 1 in relation to adapting materials for various departments is presented in the following sentence.

Interview with teacher 1

"My English knowledge is more likely to English for general purpose. So, nine various departments, I teach the same material."

Based on the teacher 1 explanation, she taught the students from different departments by using the same material and exercise. Her students also clarified that she taught general material based on the text book or LKS without linking to their departments. Based on the observation data, she never linking the students' department in constructing the sentences. This case is in line with teacher 3.

Interview with teacher 3

"If the teachers want to adapt the material is based on our capacity. The material for each department must be different. But the material which I teach is almost the same for every department." 
Volume I, Number 01, June 2015

The data above described that teacher 3 taught the students the same material for all departments without made the material relevance with the students' needs. Based on observation data indicated that she did not adapt or develop the material with students' department. This case was also clarified by her students.

\section{Difficult to update material from many sources}

The teachers should develop the professionalism continuously from many aspects. In interview data, there were three teachers realized that they faced difficulty in updating their professionalism. The following is their statement.

Interview with teacher 1

"The obstacle is in updating the information or material sources are rather difficult and we have to find out side."

Interview with teacher 2

"Maybe the problem is we have to facilitate our own by using modem. It means the budget, the private budget. If the school has wi-fi or internet, the best thing we can do is browsing material more often. And we have network with English teachers, we can improve it better."

Interview with teacher 3

"Sometimes I want to improve my professionalism but the problem is inadequate facility."

The data indicated that they faced problem to access internet. They consider that internet media is a good media to update and learn the information from different sources. But the school did not facilitate the teachers.

\section{Lacking of teacher developing activities}

Another aspect to develop the professionalism continuously is by involving in every kinds of developing activities namely Teacher Group working, Teacher Group Working of Subject Matter and so on. Teacher 1 believed that teachers' group working can influence the professionalism because if we shared with other teachers can give us new information for our teaching. Nevertheless, she also never attended the forum. In addition even teacher 2 and teacher 3 did not attend the teachers group working activities. It can be seen by their explanation in the following.

Interview with teacher 2

"I have not heard yet."

Interview with teacher 3

"Oh... I do not know, there is not." 
Syamsinar, The Problems In Professional Competence of Teachers In Teaching English Subjet ...

The data showed that teachers of vocational high school in Gowa region especially in Somba Opu district were still lacking of teacher developing activities.

\section{Do not use information and communication technology for communicating effectively}

The use of media in teaching and learning process makes the teaching and learning activities becomes more interesting and effective. Nevertheless, the teachers in the school did not maximize the utilizing of information and communication technology. Based on research findings, the teachers did not use the information and communication effectively. It can be proved by data of teachers' interview and observation. Even the teachers had been facilitated with LCD, teacher 2 and teacher 3 were rarely to use it in the teaching process. This was also clarified by the students' of teacher 2 in interview. They stated that they had been teaching about two semesters by those teachers, but the teachers never used LCD in the classroom.

Meanwhile, during the observation in another school found that teacher 4 did not use the language laboratory in teaching. This information was also gained by his students of grade X and grade XI. They uttered that they had not been taught in the language laboratory. By this case, the benefit of media did not apply maximally by the teachers in teaching.

\section{Lacking of classroom management}

The professional teacher is demanded to be able to have good management. The good management can be seen by the capability of teacher in managing the time, material and classroom. This challenge is also faced by the teacher 1 in the classroom. In findings, the students of teacher 1 informed that she was lacking in managing the students in the class especially when she explained the material. They stated that some of their friends in the class were still noise when she explained the material. The researchers also found that she let the students to operate their hand phone during the learning process.

\section{E. DISCUSSION}

Based on the result of the research indicated that there were eleven problems in professional competence faced by the teachers in teaching English subject at vocational high schools in SombaOpu sub-district. The teachers of vocational high schools were still lacking of vocabulary used for various departments, this case is in accordance with Kaimuddin (1999). In addition the teachers also dominantly used 
Indonesian language in communicating the material, Rodriguez (2012). Dealing with the teaching device, the beginner teacher still faced problem to achieve basic competence, this case is in line with Padmadewi (2007). In other side, she taught the material based on the module instruction without having the lesson plan (Syamsuri, 2010). In delivering the materials the beginner teachers faced difficulties to select the appropriate materials. Sometimes, even they realized that the material is not appropriate to be taught for student but they did not change it (Ghufron, 2012). Whereas, the advance beginner teacher and expert teacher did not develop the material to be linked to the students' department activities or tools. This case is accordance with Tomlinson (2003). Thus, it is important for teachers to be involved in the teacher group working to discuss their obstacles in the class especially dealing with the material. In fact, three of four teachers never involve in the teacher group working activities. In terms of the utilizing media in teaching three teachers still did not utilize the information and communication technology maximally. This problem is accordance with Liuzhi (2012) found that most teachers in vocational colleges are still adopting the mode of language-based "textbook+ blackboard". These problems are the aspects of professional competence of the Regulation of National Education Minister and Culture of Republic of Indonesia No. 16/2007, Slavik (2008) and Bantang (2008).

In other side, there was one of the advance beginner teachers who was low of classroom management, Ayuni (2013). This problem is the part of professional competence based on Bantang (2008).

\section{F. CONCLUSION}

In English teachers' competence especially in linguistic aspect, the major problem faced by the teachers is dealing with lacking of the vocabulary of special terms. On the contrary, the minor problem in linguistic aspect is in pronunciation aspect. Whereas, communicative competence is considered to be the medium problem of English teachers' professional competence, because of the four participants, two participants faced difficulty in communicating the lesson. In addition, other serious problems also faced by the teachers in developing the teacher professionalism continuously and do not use information and communication for communicating maximally.

Based on the findings, the researchers concluded that the professional competence of English teacher at SMKN 1 SombaOpu and SMKN 2 SombaOpu are 
still low. The teacher who had the lowest professional competence is advanced beginner teacher or honorary teacher from SMKN 2 SombaOpu. And the teacher who had the highest professional competence is the expert English teacher of SMKN 2 SombaOpu. He has been certified. He had also attended the educational trainings and technical terms educational training, teacher group working of subject matter and involved in action research competition.

Nevertheless, among the group of expert teacher, it was found that an expert teacher of English who comes from other discipline is not the same with the real expert teacher of English in terms the professional competence. This is due to the low of linguistic aspect. Dealing with she had attended the educational training and PLPG, she is good in teaching planning and selecting the material.

\section{G. SUGGESTION}

To be a professional teacher, the teacher must possess the professional competence either the professional competence based on The Regulation of National Education Ministry of Republic of Indonesia No. 16/2007, Slavík (2008) or Bantang (2008). The English teachers of SMKN 1 SombaOpu and SMKN 2 SombaOpu still need to improve the professional competence especially the English teacher professional competence in linguistic aspect.

In addition, the researchers suggested the government and the Educational trainer differentiate with the senior high school. Especially for vocational high school teachers should be facilitated with education training of ESP knowledge. Henceforth, the government and the certificated organizer must be consistent in terms of teachers' academic qualifications.

\section{REFERENCES}

Arsana, A. A. 2012. Studi Evaluatif Tentang Pelaksanaan Standar Proses Dalam Pembelajaran Bahasa Inggris Pada Siswa Tingkat Pertama di SMK Negeri 1 Denpasar. A thesis. Singaraja: program pascasarjana Universitas Pendidikan Ganesha Singaraja

Ayuni. 2013. Pengelolaan Kelas Dalam Pembelajaran. Retreived at Augut $7^{\text {th }} 2014$ from http://www. cademia.edu//MakalahPengelolaanKelas_Dalam_Pembelajaran

Bantang, Sirajuddin. 2008. Guru Sebagai Pendidik Yang Humanis. Makassar: Pustaka Refleksi 
Dreyfus. 1986. Novice to Expert: the Dreyfus model of skill acquisition. Retrieved from http://www.sld.demon.co.uk/dreyfus/pdf.

Gay, L.R., et al. 2006. Educational Research. Pearson: Merrill Prentice Hall.

Ghufron, Syamsul. 2012. Problematika Pembelajaran Aspek Kebahasaan di Sekolah dan Solusinya. Universitas Darul Ulum Lamongan.

Huaxiao Zhu. 2012. Discussion about Vocational English Teaching Reform. International Conference on Education Technology and Management Engineering: Lecture Notes in Information Technology, Vols.16-17. Retrieved at December 5, 2013 from http://www.iier.org.au/iier15/breen.html.

Kaimuddin. 1999. Need Analysis of Technical English for Technical High School Students. Dissertation. Makassar: Postgraduate Program Hasanuddin University.

Mulyasa.2007c. Standar Kompetensi dan Sertifikasi Guru. Bandung: Remaja Rosdakarya.

Peraturan Menteri Pendidikan Nasional Republik Indonesia Nomor 16 Tahun 2007. Standar Kualifikasi Akademike dan Kompetensi Guru. Jakarta: Menteri Pendidikan Nasional

Suharini. 2009. StudiTentangKompetensiPedagogik Dan ProfesionalBagi Guru Geografi Di SmaNegeriKabupatenPati. Retreived at Augut $7^{\text {th }} 2014$ from http://journal.unnes.ac.id/nju/index.php/JG/article/view/99

Suwito, Erlin. 2012. ProblematikaPengembanganKompetensi Professional Guru PAI di MTs PGRI Selur. Referred Academic Journal.iiste.org.Retrieved at July $10^{\text {th }}$ 2014 from www.scribd.com/doc/158163037-problematika-pengembangankompetensi-professional-guru-PAI-di-MTs-PGRI-Selur.

Wello, Muhammad \&Nur, Hafsah. 1999. An Introduction to ESP (English for Spesific Puppose).Published: BadanPenerbitUniversitasNegeri Makassar. 